\title{
Lepidoptera of a raised bog and adjacent forest in Lithuania
}

\author{
DALIUS DAPKUS
}

Department of Zoology, Vilnius Pedagogical University, Studentu 39, LT-2004 Vilnius, Lithuania; e-mail: daldap@vpu.lt

Key words. Lepidoptera, tyrphobiontic and tyrphophilous species, communities, raised bog, wet forest, Lithuania

\begin{abstract}
Studies on nocturnal Lepidoptera were carried out on the Laukenai raised bog and the adjacent wet forest in 2001. Species composition and abundance were evaluated and compared. The species richness was much higher in the forest than at the bog. The core of each lepidopteran community was composed of 22 species with an abundance of higher than $1.0 \%$ of the total catch. Tyrphophilous Hypenodes humidalis (22.0\% of all individuals) and Nola aerugula (13.0\%) were the dominant species in the raised bog community, while tyrphoneutral Pelosia muscerda (13.6\%) and Eilema griseola $(8.3 \%)$ were the most abundant species at the forest site. Five tyrphobiotic and nine tyrphophilous species made up $43.4 \%$ of the total catch on the bog, and three and seven species, respectively, at the forest site, where they made up $9.2 \%$ of all individuals. $59 \%$ of lepidopteran species recorded on the bog and $36 \%$ at the forest site were represented by less than five individuals. The species compositions of these communities showed a weak similarity. Habitat preferences of the tyrphobiontic and tyrphophilous species and dispersal of some of the species between the habitats are discussed.
\end{abstract}

\section{INTRODUCTION}

The insect fauna of isolated raised bogs in Europe is unique in having a considerable portion of relict boreal and subarctic species (Mikkola \& Spitzer, 1983; Spitzer \& Jaroš, 1993; Spitzer et al., 1999). Arthropod communities associated with raised bogs are very sensitive to natural or man induced successional processes (Spitzer, 1994; Vepsäläinen et al., 2000). The relict insect fauna of closed climax pine forests is much less diverse and composed mostly of abundant tyrphophilous and tyrphoneutral forest species. In peatland habitat islands preservation or restoration of hydrological conditions, which prevent successional change to closed dense pine forest, is the basic management strategy for habitat conservation of all relict tyrphobiontic species (Spitzer, 1994; Spitzer et al., 1999). Such islands and their insect communities are unique and have persisted in these bogs since the early Holocene, and the complete habitat conservation of each locality is needed for preservation of all these stenotopic species (Tillotson \& Spitzer, 1998). As only a few field studies have been carried, a comparative study of insects associated with basic successional stages of peat bogs is necessary (Väisänen, 1992; Spitzer \& Jaroš, 1993; Spitzer et al., 1999).

\section{MATERIAL AND METHODS}

Nocturnal Lepidoptera were studied on the Laukenai raised bog and in the surrounding wet forest (central Lithuania, $55^{\circ} 11^{\prime} \mathrm{N}, 25^{\circ} 03^{\prime} \mathrm{E}$ ). The studies were carried out from April until November 2001. Jalas model automatic light traps with $160 \mathrm{~W}$ blended lamp bulbs were used to trap the Lepidoptera (Jalas, 1960; Söderman, 1994; Leinonen et al., 1998). One trap was operated on the raised bog and another in the adjacent forest. Each trap was emptied once a week (in total, 56 samples were collected). Species of Lepidoptera belonging to the superfamilies Lasiocampoidea, Bombycoidea, Drepanoidea, Geometroidea and Noctuoidea were identified to species level and used in the analysis. The nomenclature follows Karsholt \& Razowski
(1996). Ecological terminology is that of Mikkola \& Spitzer (1983), Spitzer \& Jaroš (1993), Spitzer (1994): tyrphobiontic species are species that are strongly associated with peat bogs, while tyrphophilous taxa are more abundant on bogs than in adjacent habitats. Tyrphoneutral species occur in various habitats and show no preference for peat bogs.

The structure of the vegetation was evaluated using frame quadrats (Väisänen, 1992; Bullock, 1996). Species composition of the trees and their height was recorded for three randomly selected $5 \times 5 \mathrm{~m}$ squares at a distance of $150 \mathrm{~m}$ from the margin between the bog and forest. Percentage cover of species in the undergrowth was recorded using four randomly selected subsquares of $0.25 \times 0.25 \mathrm{~m}$ in the above squares. The nomenclature used to describe the plant communities follows Pott (1992) and Matuszkiewicz (2001).

The rarefaction method was used to compare species richness between the lepidopteran communities in the raised bog and adjacent forest (Krebs, 1999). The species composition of the lepidopteran communities was compared using the binary coefficient of Sorensen (SQ). It ranges from 0 (no similarity) to 1.0 (complete similarity). It was calculated for all the species, and for those that were represented by more than five individuals in each community.

\section{Description of the study sites}

1. The bog. Laukenai raised bog (64.1 ha) is covered by interspersed dense and open Ledo-Pinetum R. Tüxen 1955 communities. The study site is covered with dense pine growth reaching up to $5 \mathrm{~m}$ in height (Fig. 1). Single birches are scattered throughout the bog. Eriophorum spp. is the dominant species in the undergrowth (coverage 38\%) (Fig. 3). Some parts are covered with dense Vaccinium uliginosum L. (15\%) and Ledum palustre L. (9\%) shrub. Calluna vulgaris (L.) is scarce and found only in some dryer parts of the bog. The coverage of Sphagnum mosses is approximately $70-80 \%$.

2. The forest. The bog is surrounded by wet forest. The forest site is covered with dense Molinio-Pinetum J. Matuszkiewicz 1973 plant communities. Pines reaching up to $7-20 \mathrm{~m}$ in height are abundant in the study area (Fig. 2). There are many young birches 1-2 m high, while few birches reach $15 \mathrm{~m}$ in height. Saplings of Picea abies (L.), Quercus robur L., 


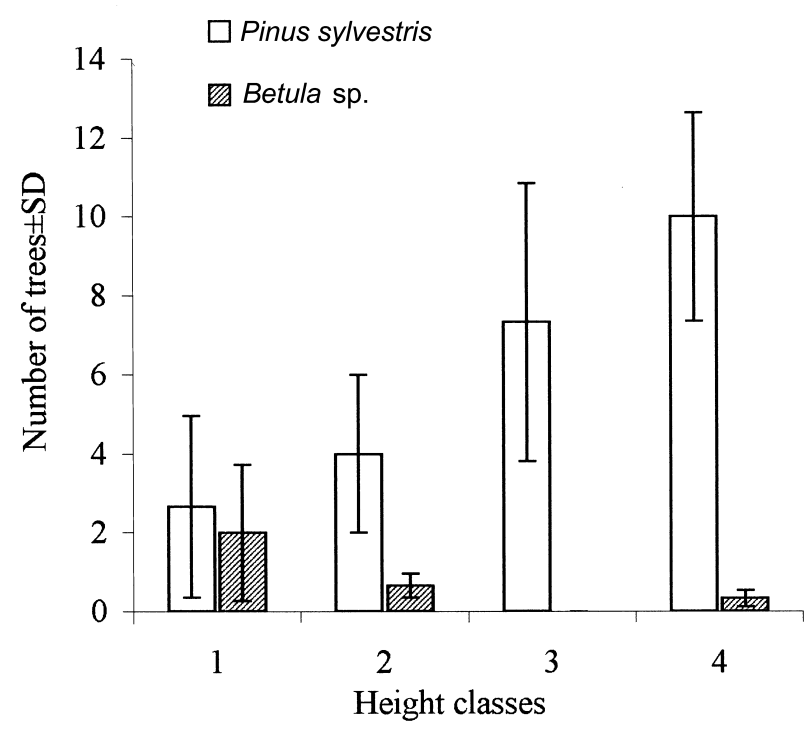

Fig. 1. Mean number of trees and their height on the $5 \times 5 \mathrm{~m}$ quadrats $(\mathrm{N}=3)$ sampled on the Laukenai raised bog. Height classes: $1-<1 \mathrm{~m}, 2-<2 \mathrm{~m}, 3-<3 \mathrm{~m}, 4-<5 \mathrm{~m}$ height.

Sorbus aucuparia L. and Padus avium Mill. are scattered in the forest. Vaccinium myrtillus L. is the dominant shrub, covering about $41 \%$ of the ground (Fig. 3). Some places are covered with Vaccinium vitis-idea L., Ledum palustre L. and Eriophorum spp. Pleurozium schreberi (Brid.) is the dominant moss (coverage 40-50\%). Agricultural fields used for extensive pasture and haymaking surround the forest.

\section{RESULTS}

A total of 41011 specimens of Lepidoptera belonging to 422 species were recorded during the study. Of these, 294 species (12 201 specimens) were found on the raised bog, and 388 species (28 810 specimens) in the adjacent wet forest. Analysis by rarefaction showed that species richness was much higher in the forest than at the bog site (Fig. 4).

The core of each lepidopteran community was composed of 22 species (abundance equal to or greater than $1.0 \%$ of all individuals). These formed $77.9 \%$ of the total lepidopteran catch from the bog and $61.4 \%$ from the forest site. Of these, one tyrphobiontic (Carsia sororiata) and five tyrphophilous species (Arichanna melanaria, Itame brunneata, Hypenodes humidalis, Celaena haworthii and Nola aerugula) were recorded from the raised bog, while three tyrphophilous species (Arichanna melanaria, Hypenodes humidalis and Nola aerugula) were found at the forest site (Table 1). The six stenotopic species mentioned made up $41.9 \%$ of all individuals recorded from the bog, while the pooled abundance of three tyrphophilous species was $8.1 \%$ of all individuals from the forest site.

Tyrphophilous Hypenodes humidalis and Nola aerugula were the dominant species on the raised bog (Table 1). They constituted $35.0 \%$ of the total lepidopteran catch. Other stenotopic species were less abundant on the bog and varied from $2.5 \%$ (Arichanna melanaria) to $1.1 \%$ (Itame brunneata). The abundance of tyrphoneutral species greater than $1.0 \%$ of the total catch made up $36.0 \%$
TABLE 1. The most abundant species of Lepidoptera trapped at the Laukenai raised bog and forest in 2001. TB - tyrphobiontic, $\mathrm{TF}$ - tyrphophilous species.

\begin{tabular}{|c|c|c|c|c|}
\hline \multirow{2}{*}{$\begin{array}{l}\text { Species } \\
\text { Poecilocampa populi (Linnaeus) }\end{array}$} & \multicolumn{2}{|c|}{$\begin{array}{c}\text { Bog } \\
\text { No. ind. }(\%) \\
\end{array}$} & \multicolumn{2}{|c|}{$\begin{array}{c}\text { Forest } \\
\text { No. ind. (\%) }\end{array}$} \\
\hline & 132 & (1.1) & 155 & $(0.5)$ \\
\hline Euthrix potatoria (Linnaeus) & 160 & (1.3) & 168 & $(0.6)$ \\
\hline Tetheella fluctuosa (Hübner) & 11 & $(0.1)$ & 154 & $(0.5)$ \\
\hline Ochropacha duplaris (Linnaeus) & 13 & $(0.1)$ & 456 & (1.6) \\
\hline Falcaria lacertinaria (Linnaeus) & 46 & $(0.4)$ & 209 & $(0.7)$ \\
\hline Lomaspilis marginata (Linnaeus) & 6 & $(0.05)$ & 405 & (1.4) \\
\hline Macaria alternaria (Hübner) & 1 & $(0.01)$ & 129 & $(0.4)$ \\
\hline Chiasma clathrata (Linnaeus) & 46 & $(0.4)$ & 335 & $(1.2)$ \\
\hline Itame brunneata $\left(\right.$ Thunberg) ${ }^{\mathrm{TF}}$ & 133 & $(1.1)$ & 207 & $(0.7)$ \\
\hline Cepphis advenaria (Hübner) & 4 & $(0.0)$ & 104 & $(0.4)$ \\
\hline Deileptenia ribeata (Clerck) & 17 & $(0.1)$ & 156 & $(0.5)$ \\
\hline Arichanna melanaria (Linnaeus) $^{\mathrm{TF}}$ & 302 & $(2.5)$ & 310 & (1.1) \\
\hline Hypomecis punctinalis (Scopoli) & 2 & $(0.02)$ & 103 & $(0.4)$ \\
\hline Cabera pusaria (Linnaeus) & 15 & $(0.1)$ & 267 & $(0.9)$ \\
\hline Cabera exanthemata (Scopoli) & 9 & $(0.1)$ & 471 & (1.6) \\
\hline Cyclopohora albipunctata (Hufnagel) & 10 & $(0.1)$ & 211 & $(0.7)$ \\
\hline Timandra comai A. Schmidt & 56 & $(0.5)$ & 339 & $(1.2)$ \\
\hline Scopula immutata (Linnaeus) & 76 & $(0.6)$ & 301 & $(1.0)$ \\
\hline Scopula ternata Schrank & 106 & $(0.9)$ & 198 & $(0.7)$ \\
\hline Idaea biselata (Hufnagel) & 43 & $(0.4)$ & 694 & $(2.4)$ \\
\hline Scotopteryxchenopodiata (Linnaeus) & 20 & $(0.2)$ & 133 & $(0.5)$ \\
\hline Xanthorhoe ferrugata (Clerck) & 99 & $(0.8)$ & 532 & (1.8) \\
\hline Eulithis testata (Linnaeus) & 217 & (1.8) & 113 & $(0.4)$ \\
\hline Eulithis populata (Linnaeus) & 18 & $(0.1)$ & 403 & (1.4) \\
\hline Chloroclysta citrata (Linnaeus) & 33 & $(0.3)$ & 130 & $(0.5)$ \\
\hline Pennithera firmata (Hübner) & 136 & $(1.1)$ & 81 & $(0.3)$ \\
\hline Hydriomena furcata (Thunberg) & 1 & $(0.01)$ & 183 & $(0.6)$ \\
\hline $\begin{array}{l}\text { Epirrita dilutata } \\
\text { (Denis \& Schiffermüller) }\end{array}$ & 150 & $(1.2)$ & 20 & $(0.1)$ \\
\hline Epirrita autumnata (Borkhausen) & 84 & $(0.7)$ & 1055 & (3.7) \\
\hline Perizoma alchemillatum (Linnaeus) & 16 & $(0.1)$ & 145 & $(0.5)$ \\
\hline Rhinoprora debiliata (Hübner) & 20 & $(0.2)$ & 257 & $(0.9)$ \\
\hline Carsia sororiata $\left(\right.$ Hübner) ${ }^{\mathrm{TB}}$ & 213 & $(1.7)$ & 0 & $(0.0)$ \\
\hline $\begin{array}{l}\text { Hydrelia sylvata } \\
\text { (Denis \& Schiffermüller) }\end{array}$ & 13 & $(0.1)$ & 250 & (0.9) \\
\hline Pheosia gnoma (Fabricius) & 34 & $(0.3)$ & 153 & $(0.5)$ \\
\hline Hypenodes humidalis Doubleday ${ }^{\mathrm{TF}}$ & 2686 & $(22.0)$ & 1725 & $(6.0)$ \\
\hline Rivula sericealis (Scopoli) & 186 & $(1.5)$ & 1213 & $(4.2)$ \\
\hline Diachrysia chrysitis (Linnaeus) & 43 & $(0.4)$ & 109 & $(0.4)$ \\
\hline Protodeltote pygarga (Hufnagel) & 9 & $(0.1)$ & 333 & $(1.2)$ \\
\hline $\begin{array}{l}\text { Pseudeustrotia candidula } \\
\text { (Denis \& Schiffermüller) }\end{array}$ & 141 & $(1.2)$ & 132 & $(0.5)$ \\
\hline Agrochola helvola (Linnaeus) & 146 & $(1.2)$ & 24 & $(0.1)$ \\
\hline Chortodes pygmina (Haworth) & 10 & $(0.1)$ & 190 & $(0.7)$ \\
\hline Celaena hawortii (Curtis) ${ }^{\mathrm{TF}}$ & 189 & $(1.5)$ & 31 & $(0.1)$ \\
\hline Orthosia incerta (Hufnagel) & 46 & $(0.4)$ & 188 & $(0.7)$ \\
\hline Orthosia gothica (Linnaeus) & 76 & $(0.6)$ & 265 & $(0.9)$ \\
\hline Xestia c-nigrum (Linnaeus) & 968 & (7.9) & 287 & $(1.0)$ \\
\hline Euproctis similis (Fuessly) & 4 & $(0.03)$ & 215 & $(0.7)$ \\
\hline Nola aerugula ${\text { (Hübner) }{ }^{\mathrm{TF}}}$ & 1584 & $(13.0)$ & 302 & (1.0) \\
\hline Thumata senex (Hübner) & 344 & $(2.8)$ & 364 & (1.3) \\
\hline Miltochrista miniata (Forster) & 152 & $(1.2)$ & 1063 & (3.7) \\
\hline Cybosia mesomella (Linnaeus) & 157 & (1.3) & 445 & (1.5) \\
\hline Pelosia muscerda (Hufnagel) & 432 & (3.5) & 3925 & (13.6) \\
\hline Eilema sororcula (Hufnagel) & 9 & $(0.1)$ & 151 & $(0.5)$ \\
\hline Eilema griseola (Hübner) & 598 & $(4.9)$ & 2389 & $(8.3)$ \\
\hline Eilema lutarella (Linnaeus) & 126 & $(1.0)$ & 11 & $(0.0)$ \\
\hline Eilema complana (Linnaeus) & 353 & (2.9) & 28 & $(0.1)$ \\
\hline Eilema deplana (Esper) & 61 & $(0.5)$ & 330 & $(1.1)$ \\
\hline Eilema lurideola (Zincken) & 76 & $(0.6)$ & 103 & $(0.4)$ \\
\hline Spilosoma lubricipeda (Linnaeus) & 20 & $(0.2)$ & 208 & $(0.7)$ \\
\hline Spilosoma lutea (Hufnagel) & 5 & $(0.04)$ & 120 & $(0.4)$ \\
\hline Total & 10916 & $(89.5)$ & 23444 & (81.4) \\
\hline
\end{tabular}




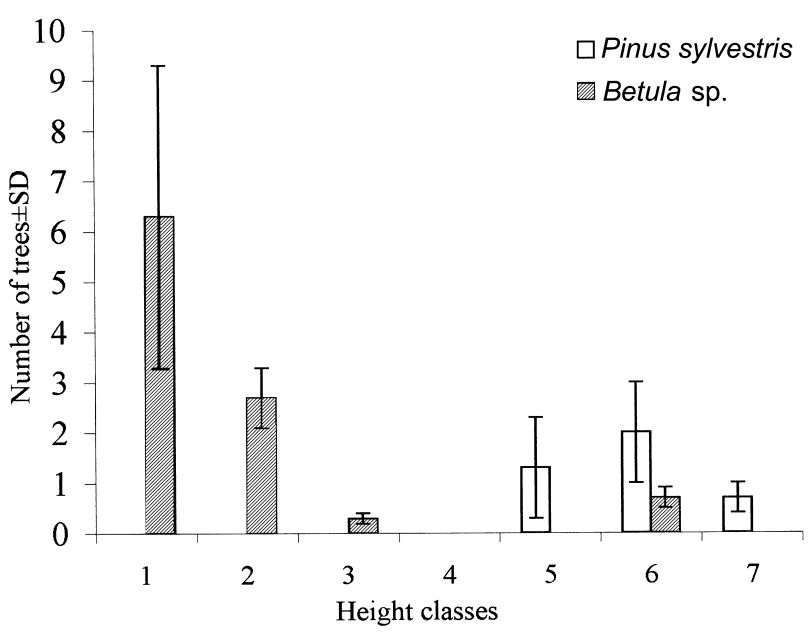

Fig. 2. Mean number of trees and their height on the $5 \times 5 \mathrm{~m}$ quadrats $(\mathrm{N}=3)$ sampled in the Laukenai forest. Height classes: $1-<1 \mathrm{~m}, 2-<2 \mathrm{~m}, 3-<3 \mathrm{~m}, 4-<5 \mathrm{~m}, 5-<10 \mathrm{~m}, 6-<15$ $\mathrm{m}, 7-<20 \mathrm{~m}$ height.

of all individuals recorded on the bog. The most common species were immigrants from the adjacent habitats (e.g. Xestia c-nigrum (7.9\%), Eilema griseola (4.9\%), Pelosia muscerda (3.5\%), etc.).

Tyrphoneutral Pelosia muscerda was the most dominant species at the forest site (13.6\%; Table 1). The abundance of Eilema griseola was $8.3 \%$, while tyrphophilous Hypenodes humidalis made up $6.0 \%$ of all individuals recorded at the forest site. Other tyrphoneutral species constituted from $4.2 \%$ (Rivula sericealis) to $1.0 \%$ (Xestia c-nigrum) of the total catch. The abundance of the two tyrphophilous species was low (Arichanna melanaria $1.1 \%$ and Nola aerugula $1.0 \%$ of the sample taken at the forest site).

Some tyrphobiontic species were recorded in extremely low numbers. Orgyia antiquoides and Coenophila subrosea were recorded only from the raised bog. Syngrapha microgamma was also found at the forest site. Another tyrphobiontic species, Chloroclysta infuscata, was recorded only from the forest site (Table 2).

TABLE 2. Tyrphobiontic and tyrphophilous species of Lepidoptera of which fewer than 100 individuals were trapped on the Laukenai raised bog and forest in 2001.

\begin{tabular}{lcc}
\hline Species & $\begin{array}{c}\text { Bog } \\
\text { No. ind. (\%) }\end{array}$ & $\begin{array}{c}\text { Forest } \\
\text { No. ind. (\%) }\end{array}$ \\
\hline Tyrphobiontic & & \\
Chloroclysta infuscata (Tengström) & $0(0.0)$ & $4(0.01)$ \\
Acronicta menyanthidis (Esper) & $28(0.2)$ & $5(0.02)$ \\
Syngrapha microgamma (Hübner) & $1(0.01)$ & $1(0.004)$ \\
Coenophila subrosea (Stephens) & $3(0.03)$ & $0(0.0)$ \\
Orgyia antiquoides (Hübner) & $1(0.01)$ & $0(0.0)$ \\
Tyrphophilous & & \\
Idaea muricata (Hufnagel) & $3(0.03)$ & $0(0.0)$ \\
Amphipoea lucens (Freyer) & $62(0.5)$ & $4(0.02)$ \\
Papestra biren (Goeze) & $10(0.1)$ & $0(0.0)$ \\
Lithomoia solidaginis (Hübner) & $78(0.6)$ & $58(0.2)$ \\
Total & $186(1.48)$ & $72(0.25)$ \\
\hline
\end{tabular}

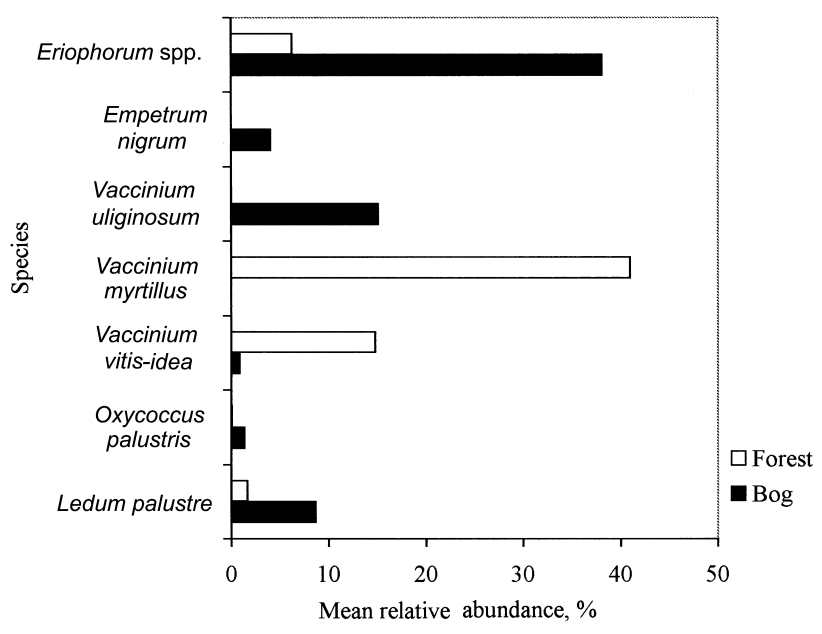

Fig. 3. Mean relative abundance (\%) of the undergrowth in the $0.25 \times 0.25 \mathrm{~m}$ quadrats $(\mathrm{N}=4)$ sampled on the Laukenai raised bog and forest site in 2001 .

Most of the tyrphophilous species were more abundant on the bog than at the forest site. Idaea muricata and Papestra biren were found only on the bog, and the abundances of Nola aerugula, Hypenodes humidalis, Celaena haworthii and Amphipoea lucens were much higher on the bog than at the forest site (Table 1,2). The number of specimens of the tyrphophilous species Lithomoia solidaginis was similar in both communities. The total catches of Itame brunneata and Arichanna melanaria were higher in the forest than on the raised bog. Tyrphobiontic and tyrphophilous species constituted $43.4 \%$ of the total catch of Lepidoptera on the raised bog and 9.2\% at the forest site.

On the bog, 120 species (41\%) were found in low numbers (1-2 individuals). At the forest site, low numbers for 90 species $(23 \%)$ were recorded. On the raised bog, the number of individuals of 53 species $(18.0 \%)$ varied from three to five, and the abundances of 121 species (41.2\%) were higher than five individuals. At the forest site, the abundances of 49 species $(12.6 \%)$ varied from three to five individuals, and for 249 species $(64.2 \%)$ more than five individuals were collected.

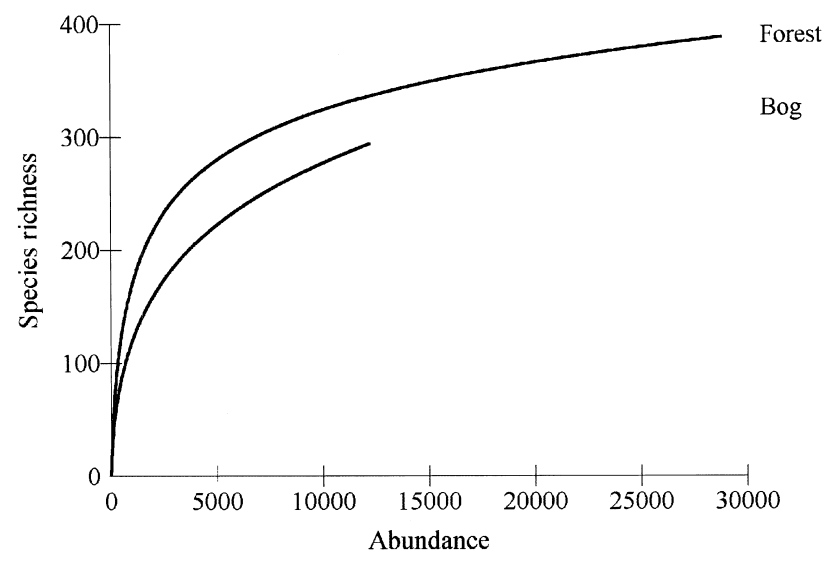

Fig. 4. A comparison of species richness of the lepidopteran communities of the Laukenai raised bog and forest using the rarefaction method. 
For all the species, the Sorensen's similarity index indicated that the communities were similar in species composition ( $\mathrm{SQ}=0.76$ ). As many as 260 species were common to both lepidopteran communities, 34 species were characteristic of the raised bog, and 128 only of the forest site. The analysis of the data set, comprising species with more than five individuals, indicated that the lepidopteran communities were less similar $(\mathrm{SQ}=0.57)$. After the elimination of rare species, there were 105 species common to both communities, while 16 lepidopteran species were characteristic of the raised bog and 144 of the forest site.

\section{DISCUSSION AND CONCLUSIONS}

The results show that fewer lepidopteran species inhabit the raised bog and their abundance is much lower than in adjacent wet forest with some elements of bog vegetation. It is known that the diversity of tyrphobiontic and some tyrphophilous lepidopteran species is much lower in climax forest and the most specific peatland taxa are associated with early successional phases of bogs (Spitzer et al., 1999). The cores of the lepidopteran communities were composed of the same number of species. Six tyrphobiontic and tyrphophilous lepidopteran species were dominant on the raised bog, and their pooled abundance reached nearly half of the total catch. Only three tyrphophilous species were abundant in the forest lepidopteran community, making up approximately $8 \%$ of all individuals.

According to Spitzer et al. (1999), tyrphobiontic and tyrphophilous lepidopteran species are found in bog climax pine forests and adjacent peatlands. Tyrphophilous Hypenodes humidalis and Nola aerugula were the most abundant species on the raised bog, together constituting one third of the total lepidopteran catch. Both species are dominant in other Lithuanian peat bogs (Dapkus, 2001b). Hypenodes humidalis prefers open Sphagnum sites in Central Europe (Spitzer et al., 1999), but our results reveal that it lives on dense pine bogs. Nola aerugula seems to prefer bog habitats, as it was less abundant at the forest site. It is trophically associated with birch (Betula spp.; Spitzer \& Jaroš, 1993), which was scarce at both sites.

Tyrphophilous Arichanna melanaria and Itame brunneata are trophically associated with Vaccinium uliginosum and Ledum palustre (Spitzer \& Jaroš, 1993). Both species were quite abundant at both the bog and forest sites. The number of specimens of $A$. melanaria and $I$. brunneata trapped in the forest was higher than on the bog. The impact of these species on the bog lepidopteran community was greater due to the lower species richness. A. melanaria is a tyrphobiontic species and characteristic of the edaphic bog climax pine forests in Central Europe (Spitzer et al., 1999). Our results reveal that it is a tyrphophilous species in Lithuania, associated with dense pine bogs and wet forests with Vaccinium spp.

Tyrphobiontic Carsia sororiata was recorded only at the bog site. It is strictly associated with raised bogs and does not migrate to adjacent habitats (Dapkus, 2001a).
The tyrphobiontic Coenophila subrosea was also not recorded at the forest site but does migrate to the margins of bogs and other peatlands (Dapkus, 2001b). Tyrphophilous Papestra biren was recorded only on the bog but is also found in wet mature forests in Lithuania (Švitra, pers. comm.). Chloroclysta infuscata is considered to be strictly associated with peat bogs (Dapkus, 2001a, b). It is a tyrphobiontic species, which prefers wet ecotones between successional stages of peat bogs and bog climax forests in Central Europe (Spitzer et al., 1999). It lives at the margins of pine bogs and wet coniferous woodlands in Finland (Mikkola, 1976; Mikkola \& Spitzer, 1983). The results presented here show that its association with peat bogs is not very strict as it is found in wet mature woodlands with Vaccinium spp. or at the margins of raised bogs in Lithuania.

The abundances of tyrphobiontic Acronicta menyanthidis and tyrphophilous Celaena haworthii and Amphipoea lucens, were much higher on the raised bog than at the forest site. These species are all strictly associated with peat bogs in Central Europe (Spitzer \& Jaroš, 1993, 2001; Spitzer et al., 1999), while their association is moderate or weak in Finland, where they can be found in fens and humid grasslands (Mikkola, 1976; Mikkola \& Spitzer, 1983). A. lucens is common in archipelagoes as well.

The abundance of Lithomoia solidaginis was similar at both the sites studied. It is trophically associated with Vaccinium uliginosum and V. myrtillus (Kazlauskas, 1984). V. uliginosum was abundant on the bog, V. myrtillus at the forest site. L. solidaginis is a tyrphophilous species in Lithuania. It is found on raised bogs and in wet mature forests (Dapkus, 2000, 2001b).

Tyrphobiontic Orgyia antiquoides and Syngrapha microgamma were recorded singly at the bog site. A single specimen of the latter species was also recorded from the surrounding forest. Both species are heliophilous, so their presence in the light traps is accidental.

In this study, $41 \%$ of all lepidopteran species were represented by more than five individuals on the raised bog, and $60 \%$ of all species were very rare residents or temporal immigrants from the surrounding habitats. They disperse from adjacent habitats but do not establish populations, possibly because of the specific microclimatic conditions characteristic of peat bogs (Mikkola \& Spitzer, 1983; Spitzer, 1994; Vepsäläinen et al., 2000). A different situation was observed at the forest site, where $64 \%$ of all species were represented by more than five individuals and $36 \%$ were immigrants or rare residents. Forests have more diverse vegetation than raised bogs and their microclimatic conditions are more favourable for tyrphoneutral species. Even a climax forest habitat island with relatively stable vegetation is prone to invasion by species of Lepidoptera from surrounding habitats (Lepš et al., 1998).

The results show that some tyrphoneutral species associated with agricultural landscapes migrate through the forest to the bog (e.g. Chiasmia clathrata, Scotopteryx chenopodiata, Rivula sericealis, Diachrysia chrysitis, 
etc.). Their abundance is usually lower in the latter habitat. Only the number of specimens of Xestia c-nigrum recorded from the bog was much higher than in the adjacent forest ( 968 vs. 287 individuals). It is a polyphagous species, preferring open ruderal and agricultural habitats and sometimes migrates in masses (Kazlauskas, 1984; Fibiger, 1993).

Some species of forest Lepidoptera disperse to the bog, but in low numbers. Only some arctiids were very abundant at the forest site (e.g. Miltochrista miniata, Pelosia muscerda, Eilema griseola, E. depressa, E. lurideola, etc.). These species are usually found in deciduous and coniferous forests in Lithuania (Kazlauskas, 1984). They are abundant in wetland and forest habitats in Central Europe (Spitzer et al., 1999). The geometrids Epirrita autumnata, Scopula immutata and Xanthorhoe ferrugata, and the noctuids Orthosia incerta and O. gothica were represented by more than 50 individuals on the bog, but their abundance was much higher at the forest site. They are characteristic forest species (Kazlauskas, 1984). The abundance of some species (Eulithis testata, Epirrita dilutata, Eilema lutarella, Eilema complana, Agrochola helvola and Pseudeustrotia candidula) was higher on the bog than at the forest site. They are usually found in wet forests in Lithuania (Kazlauskas, 1984) and possibly come from the margins of the bog.

Comparison of the lepidopteran communities shows that they are similar if all the species are included in the analysis, as a large number of species are common to both. Many of the rare species on the bog come from surrounding habitats, so another set of data was analysed. It indicates that the similarity of the communities is weak, due to the large number of characteristic species at the forest site.

The results emphasize the unique character of raised bogs and the need for them to be protected. Even a small raised bog contains a strong complex of tyrphobiontic and tyrphophilous species of Lepidoptera. These species are good indicators of the stability of a bog. Human activities can lead to irreversible changes in the vegetation and lepidopteran communities living on peat bogs.

ACKNOWLEDGEMENTS. I wish to thank Giedrius Švitra (Lithuania) and Jaakko Kullberg (Finnish Museum of Natural History, Finland) for comments on the association of some species of Lepidoptera with peat bogs. I am also thankful to Stephen Venn (Helsinki University, Finland) for improving the English of this manuscript and two anonymous referees for constructive reviews and critical comments.

\section{REFERENCES}

Bullock J. 1996: Plants. In Sutherland W.J. (ed.): Ecological Census Techniques: a Handbook. Cambridge University Press, pp. 111-117.
DAPKUS D. 2000: Comparison of Lepidoptera communities of Čepkeliai raised bog, Baloša and Palios peatlands. Acta Zool. Lituan. 10: 85-88.

DAPKUS D. 2001a: Macrolepidoptera of Lithuanian peat bogs. Norw. J. Entomol. 48: 161-166.

DAPKUS D. 2001b: Macrolepidoptera in South-eastern Lithuanian raised bogs. Ekologija 2: 33-39.

Fibiger M. 1993: Noctuidae Europeae. Vol. 2. Noctuinae II. Entomological Press, Sorø, 230 pp.

JALAS I. 1960: Eine leichtgebaute, leichttransportable Lichtreuse zum Fangen von Schmetterlingen. Ann. Entomol. Fenn. 26: 44-50.

Karsholt O. \& Razowski J. (eds) 1996: The Lepidoptera of Europe. Apollo Books, Stenstrup, 380 pp.

KazlausKas R. 1984: Butterflies and Moths of Lithuania. Mokslas Publishers, Vilnius, 190 pp. [in Lithuanian]

Krebs C.J. 1999: Ecological Methodology. Addison Wesley Longman, $620 \mathrm{pp}$.

LeinONen R., SöDERman G., ItÄmes J., RytKönen S. \& Rutanen I. 1998: Intercalibration of different light-traps and bulbs used in moth monitoring in northern Europe. Entomol. Fennica 9: $37-51$.

Lepš J., Spitzer K. \& Jaroš J. 1998: Food plants, species composition and variability of the moth community in undisturbed forest. Oikos 81: 538-548.

Matuszkiewicz W. 2001: Guide for the Identification of Plant Communities of Poland. PWN, Warszawa, 537 pp. [in Polish]

MiккоLA K. 1976: Ecological aspects of the insect fauna of Finnish peatlands. Suo 27: 3-8.

Mikkola K. \& Spitzer K. 1983: Lepidoptera associated with peatlands in central and northern Europe: a synthesis. Nota Lepidopterol. 6: 216-229.

Ротт R. 1992: Die Pflanzengesellschaften Deutschlands. Ulmer Verlag, Stuttgart, $427 \mathrm{pp}$.

SPITZER K. 1994: Biogeographical and ecological determinants of the central European peat bog Lepidoptera: The habitat island approach to conservation. Nota Lepidopterol. 5: 45-49.

SPITZER K. \& JAROŠ J. 1993: Lepidoptera associated with Červené Blato bog (Central Europe): conservation implications. Eur. J. Entomol. 90: 323-336.

SPITZER K. \& JAROŠ J. 2001: Moths and butterflies (Lepidoptera) of the Chalupska slat bog, Šumava Mountains. Sbor. Jihočes. Muz. v Čes. Budějovicich Přirodní vědy 41: 43-55.

Spitzer K., BezDĚK A. \& JAROš J. 1999: Ecological succession of a relict Central European peat bog and variability of its insect biodiversity. J. Insect Conserv. 3: 97-106.

SöDERMAN G. (ed.) 1994: Moth monitoring scheme. A handbook for field work and the data reporting. Envir. Rep. 8: 1-63.

Tillotson I.J.L. \& Sitzer K. 1998: The Rosy Marsh moth, Coenophila subrosea (Stephens, 1829) (Lepidoptera: Noctuidae) - a review of its bionomics, distribution and conservation status with special reference to Britain. Entomol. Gaz. 49: $75-89$.

VÄISÄNEN R. 1992: Distribution and abundance of diurnal Lepidoptera on a raised bog in southern Finland. Ann. Zool. Fennici 29: 75-92.

Vepsäläinen K., Savolainen R., Tiainen J. \& Vilen J. 2000: Successional changes of ant assemblages: from virgin and ditched bogs to forests. Ann. Zool. Fennici 37: 135-149. 